\title{
Accounting
}

\section{The impact of firm's life-cycle on board composition: Evidence from Vietnam's listed firms}

\author{
Duc Huy Phama* and Quoc Viet Phama
}

\begin{tabular}{l}
${ }^{a}$ University of Finance-Marketing \\
\hline C H R O N I C L E \\
\hline Article history: \\
Received May 152020 \\
Received in revised format May \\
162020 \\
Accepted July 62020 \\
Available online \\
July 142020 \\
\hline Keywords: \\
CEO duality \\
Board independence \\
Board size \\
Board composition \\
Firm's life-cycle \\
Vietnam listed firms
\end{tabular}

\begin{abstract}
A B S T R A C T
We examine the impact of the firm's life-cycle on board composition of Vietnam's listed firms. The data is balanced and covered over the period 2012-2018 for 442 Vietnam listed firms. We use a fixedeffects regressions analysis to examine the effect of a firm's life-cycle (Lifecycle), and dummy variables of firm's life-cycle (Growth, Mature, Decline) on the board composition (board size, board independence, CEO duality). Our findings show the board composition of Vietnam's listed firms tends to decrease with the firm's life-cycle. Therefore, the firms need to adjust board composition to a proper level promptly to improve their competitiveness, and consider the supervisory function of the board members is not enough positive in the life-cycle of the firms.
\end{abstract}

\section{Introduction}

The Board of Directors is widely recognized as a central role in corporate governance (Hermalin \& Weisbach, 1991) including supervision and advisory functions. Jensen and Meckling (1976) suggest that supervision is a means to assess whether a manager is committed to the owner's purpose and the role of the board of directors is to oversee the managers' activities in the interests of shareholders. Therefore, the Board is an important internal control mechanism to address the different concerns of shareholders and managers (Walsh \& Seward, 1990). In addition to supervisory functions, Adams \& Ferreira (2007) also supposed that the role of the board is to provide resources and strategies in corporate governance (Filatotchev et al., 2006). Supplying resources include providing inputs such as finance, knowledge, low cost to access resources outside the company, and the strategic advisory role of the board members to managers. Besides, Quinn and Cameron (1983) showed that companies go through stages of the life cycle including start-up, growth, maturity, and decline. Therefore, supervision and advisory functions are differences in each stage of the firm's life-cycle and a combination of these functions shows the difference in applying corporate governance. Lynall et al. (2003) showed that in the start-up stage the role of Board members with managerial duties is appropriate. And then in the growth stage, the role primarily of the board members as a consultant and providing resources from outside. Last, in the decline stage, the role of board members is supervising and providing resources from outside (Pye \& Pettigrew, 2005). Recently, (Li \& Zhang, 2018) studied the changes in board composition in life-cycle stages, the results show that size of the board decrease throughout cycles of life-cycle stages, the CEO duality had trends to separated, and the board independence is almost unchanged in life-cycle of the firms. In this article, we apply the life-cycle theory according to Anthony \& Ramesh (1992) and inherit the research of Li and Zhang (2018) to seek to identify differences in corporate governance practices of Vietnam list firms on different life-cycle stages. Given the nature of our governance data, we do not, nor can not, track within-firm changes in governance along the entire life-cycle of the firms. Instead, our focus is on identifying

* Corresponding author.

E-mail address: huypham@ufm.edu.vn (D. H. Pham)

(C) 2020 by the authors; licensee Growing Science, Canada doi: $10.5267 /$ j.ac.2020.7.013 
differences in governance practices among firms whose primary board composition.

\section{Theoretical background and hypotheses}

Jawahar and McLaughlin (2001) stated that there are differences between the variable of character corporate governance in each stage of life-cycle that is the difference in the complexity of the corporate governance structure, management capabilities, and firm's resource demand. In the start-up stage, the founders are both the owner and the management, who operate firms. When the firms going into the growth stage, it will have a significant change in management and will focus more on maintaining a beneficial per sales instead of concentrating on sales growth and taking market share. This implies that a change in corporate governance practices is necessitated because the previous success factors are no longer relevant to this more stable sales period. Therefore, it may be useful if changes are made at senior management at an appropriate time during this transition period, as this will accelerate the required changes in corporate governance. Jensen and Meckling (1976) suggested a separation of management control and ownership in corporate governance. Then, Jawahar and McLaughlin (2001) agree that in the mature stage, firms have growth rates slowed down also established several business segments, and is operated by a professional management team. At that time, the firms are usually able to generate cash and may require fewer outside resources than other stages. Besides, the firms at the decline stage are characterized by a declining sales growth rate, increased agency problems, the conflict between shareholder and managerial risen, all of that will threaten the firm's performance. Consequently, companies need to restructure to mobilize external resources to develop new products or rebuild business strategies accordingly. Filatotchev et al. (2006) assumed that the structure of the Board needs to be adjusted throughout the business life cycle to ensure the survival and development of the company. In addition, Adams and Ferreira (2007) argue that establishing an optimal board structure is effective in monitoring the behavior of managers while providing resources for the development of the company. With the functions of the board and the characteristics of the firm's life-cycle mentioned above, the structure of the Board can be flexible in response to a company's growth throughout the life-cycle of the firms. The resource dependence theory showed that companies will seek to access important resources for development (Pfeffer \& Salancik, 1978) and the Board plays an important role in consulting and introducing resources necessary for the growth of the company (Hillman \& Dalziel, 2003). Base on the issues discussed above, we propose that the board size will be expanded in the growth stage to provide external resources for the firms (Coles et al., 2008), and the board size will decrease in the maturity (decline) stage because the resources' demand is not high as growth stage. Therefore, we propose the following hypothesis:

Hypothesis $\mathrm{H}_{1}$ : The board size will be reduced through the firm's life-cycle.

Although the board size tends to decrease during the firm's life-cycle (Pfeffer \& Salancik, 1978). However, Boone et al. (2007), Goodstein et al. (1994) showed that the firms should increase to supervising the behavior of managers when changes from the growth stage to the mature stage. Moreover, According to Bonn \& Pettigrew (2009), in the early stages, the level of managerial responsibility for outside directors of the firm's start-up is low and supervision functions to the behavior of managers often encouraging and seemingly not to play a major role in corporate governance. Also, Low \& MacMillan (1988) noted down that non-executive board members in start-ups usually focused on tasks providing external resources and advisory instead of monitoring the behavior of the manager. However, many independent members can not only bring in many resources for the growth of the firms but also effectively monitor the behavior of managers during the operation of the firms. Besides that, during a period of financial difficulties, Gilson (1990) also pointed out that many independent members are appointed who have possessed some special skills or experts or representatives of creditors, banks to control the behavior of managers and strategic consultants to implement the restructuring of the firms. Therefore, we propose the following hypothesis:

Hypothesis $\mathrm{H}_{2}$ : The board independent will be increased through the firm's life-cycle.

Peng et al. (2007) assumed that start-up companies (growth) are often owned and managed by founders (family members). In this stage, the CEO and chairman are one person who will support decision making fastly, especially in urgent circumstances (D. Pham \& Pham, 2020). However, according to the agency theory, the separation of the role of the CEO and chairman to supervise the behavior of the management team is to protect the benefits of shareholders (Fama \& Jensen, 1983b). Therefore, in the maturity (or decline) stage with a diverse shareholder structure, the separation between these two positions may be helping the company ensure effective oversee the behavior of the manager. As a result, the firm will be hiring CEO professional to manage the firm's operation (Filatotchev et al., 2005). Then, we propose the following hypothesis:

Hypothesis $\mathrm{H}_{3}$ : The CEO duality will be decreased through the stage of the firm's life-cycle.

\section{Methodology}

\subsection{Sample}

The database used from financial statements and governance reports of the Vietnam list firms during 2012 to 2018 . The study also excluded financial sector companies from the sample because these companies often operated on a separate principle. Therefore, the data in this study consisted of 442 companies and 3,094 observations. According to Li and Zhang (2018), a 
majority of publicly listed companies have gone through the start-up period. Therefore, we categorize them into three stages: growth, maturity, and stagnation. Multiple financial indicators and firm age are used to classify the firm-year observations into one of the three life-cycle stages. On average, sales growth, marketing expenditure, and capital expenditure are usually higher in the growth stage, forcing companies to apply more conservative dividend policies to keep more funds. However, in the stages of maturity and stagnation, capital and marketing expenditures gradually decrease, along with sales growth rates, enabling companies to pay higher dividends. Based on the discussion above, this study uses the classification method proposed by Anthony and Ramesh (1992), Li and Zhang (2018) along with marketing expenditure rates to determine life-cycle stages. Consequently, 600 firm-year observations are in the growth stage, 1,789 are in the maturity stage, and 705 are in the stagnation stage (Pham \& Pham, 2020).

\subsection{Dependent and Independent variables}

Dependent variables: previous studies use board size, independence of the board, and the CEO duality are measured proxy for board composition (Coles et al., 2012; Li \& Zhang, 2018; Wintoki et al., 2012). In this article, we measure the board composition, including board size (BSize) is defined as the total members of the board; board independence (Indep) is defined as the ratio of independent directors to total members of the board; CEO duality (Dual) is identified as whether the board chair and CEO are one person or not. We use the dummy variable of CEO duality, which equals 1 when the CEO is also the board chair, otherwise, it equals 0 .

Independent variables: the variables of the firm's life-cycle include the growth stage (Growth), maturity stage (Mature), and the decline stage (Decline) is the dummy variable corresponding with the composited variable the firm's life-cycle (Lifecycle), and Lifecycle variable is explained with coding sequential numbers.

Control variables: Following Li \& Zhang (2018), this study uses managerial stock holdings to measure internal incentives and institutional stock holdings to control for the internal incentives and outside monitoring. The research also controls for industry and time effects. We measure the industry variable as a dummy variable: the firm's industry equals 1 , otherwise 0 . Similarly, we proxy the time variables as year dummies: the annual year equals 1 , otherwise 0 .

Model: Following Li and Zhang (2018), we use the OLS method to regress equation (1) to investigate the impacts of firm life cycle on board composition (including board size, independent director of the board, and CEO duality).

Board size $\mathrm{i}_{\mathrm{i}, \mathrm{t}}$ or IndpD $\mathrm{D}_{\mathrm{i}, \mathrm{t}}$ or Dual $_{\mathrm{i}, \mathrm{t}}=\gamma_{0}+\gamma_{1}$ Lifecycle $_{\mathrm{i}, \mathrm{t}}+\gamma_{2}$ Controls $_{\mathrm{i}, \mathrm{t}}+\varepsilon_{\mathrm{i}, \mathrm{t}}$

\subsection{Analytical Approach}

To examine the differences among the sample groups, we conducted an average difference test (Independent sample T-Test) to test whether or not the difference of board composition (board size, board independence, CEO duality) in stages of firm's life-cycle (growth, maturity, and decline). The Independent Sample T-Test indicates whether the difference between the two independent samples is the real difference or whether it is just a random effect caused by deviations from the sampling (Y. Li and Zhang, 2018). Then, we use a fixed-effects regressions analysis to examine the differences of the board composition (board size, board independence, CEO duality) in each stage of the firm's life-cycle (growth, maturity, and decline).

\section{Results}

Table 1 reports basic statistics, we have a full sample of 3,094 company-years and it presents the whole-sample descriptive statistics of board composition variables. The variable of board size has a mean of 5.470, maximum of 11, a minimum of 3 , and a standard deviation of 1.148, indicating a large difference in board size among Vietnam's listed firms. The mean of the proportion of independent board in the sample is 0.322, with a standard deviation of 0.310. Vietnam's company law and corporate governance guidelines declare that external independent directors must be one-third of the total board size.

Table 1

Descriptive statistics of board composition variables.

\begin{tabular}{lrrrrrr}
\hline Variable & \multicolumn{1}{c}{ Observation } & \multicolumn{1}{c}{ Mean } & \multicolumn{1}{c}{ Medium } & \multicolumn{1}{c}{ Maximization } & \multicolumn{1}{c}{ Minimum } & \multicolumn{1}{c}{ Standard Deviation } \\
\hline BSize & 3094 & 5.470 & 5.000 & 11.000 & 3.000 & 1.148 \\
Indep & 3094 & 0.322 & 0.286 & 1.000 & 0.000 & 0.310 \\
Dual & 3090 & 0.255 & 0.000 & 1.000 & 0.000 & 0.436 \\
\hline \hline
\end{tabular}

Our descriptive statistics show a good rate of compliance with the company law and corporate governance guidelines for 
Vietnam's listed firms. The mean of board chair-CEO duality is 0.255 , showing that for a number of Vietnam's listed firms, their CEO served as the board chair.

Table 2

Mean difference tests for board composition variables by firm's life-cycle stages.

\begin{tabular}{lrrr|rcc}
\hline \multirow{2}{*}{ Variable } & \multicolumn{2}{c}{ Firm's life-cycle stages } & \multicolumn{3}{c}{ Independent Sample T-Test } \\
& Growth & Mature & Decline & $G-M$ & $G-D$ & $M-D$ \\
\hline Observation & 600 & 1,789 & 705 & & & \\
BSize & 5.648 & 5.455 & 5.357 & $0.193^{* * *}$ & $0.291^{* * *}$ & $0.0975^{* *}$ \\
Indep & 0.339 & 0.322 & 0.308 & 0.017 & $0.031^{*}$ & 0.014 \\
Dual & 0.343 & 0.246 & 0.201 & $0.097^{* * *}$ & $0.142^{* * *}$ & $0.045^{* *}$ \\
\hline
\end{tabular}

Notes: $* p<10 \%, * * p<5 \%$ and $* * * p<1 \%$

Table 2 reports Independent Sample T-Test for board composition variables by the firm's life-cycle stages. The board size of the sample has a downward trend; the trend differs is insignificantly different between the maturity and the decline stage, but significantly between the growth - mature stage; the growth - decline stage. The proportion of independent directors is relatively steady and insignificantly different among the firm's life-cycle. CEO duality tends to descend with the firm's life-cycle, with a significant difference across the firm's life-cycle. This preliminary result indicates that the board structure is changing as a firm develops. It further reflects that there are certain relationships between the board composition and the firm's life-cycle, and the difference exists among different life-cycle stages. All the findings lay the foundation for our next regression testing.

Table 3

The impact of the firm's life-cycle on board composition

\begin{tabular}{|c|c|c|c|c|c|c|}
\hline \multirow{2}{*}{ Variables } & \multicolumn{2}{|c|}{ Bsize } & \multicolumn{2}{|c|}{ Indep } & \multicolumn{2}{|c|}{ Dual } \\
\hline & (1) & (2) & (3) & (4) & (5) & (6) \\
\hline \multicolumn{7}{|l|}{ Growth } \\
\hline \multirow[t]{3}{*}{ Mature } & $-0.1586 * * *$ & & $-0.034 * * *$ & & $-0.094 * * *$ & \\
\hline & 0.053 & & 0.012 & & 0.02 & \\
\hline & $(p=0.003)$ & & $(p=0.006)$ & & $(p=0.000)$ & \\
\hline \multirow[t]{3}{*}{ Decline } & $-0.145^{* * *}$ & & $-0.028 *$ & & $-0.145^{* * *}$ & \\
\hline & 0.2699 & & 0.014 & & 0.024 & \\
\hline & $(\mathrm{p}=0.000)$ & & $(p=0.051)$ & & $(p=0.000)$ & \\
\hline \multirow[t]{3}{*}{ Life cycle } & & $-0.1338 * * *$ & & $-0.013^{*}$ & & $-0.072 * * *$ \\
\hline & & 0.0312 & & 0.007 & & 0.012 \\
\hline & & $(p=0.000)$ & & $(p=0.068)$ & & $(p=0.000)$ \\
\hline \multirow[t]{3}{*}{ Constant } & $5.656 * * *$ & $5.775 * * *$ & $0.281 * * *$ & $0.281 * * *$ & $0.407 * * *$ & $0.465 * * *$ \\
\hline & 0.26 & 0.083 & 0.0156 & 0.019 & 0.026 & 0.032 \\
\hline & $(\mathrm{p}=0.000)$ & $(\mathrm{p}=0,000)$ & $(p=0.000)$ & $(p=0.000)$ & $(p=0.000)$ & $(\mathrm{p}=0.000)$ \\
\hline Industry & Yes & Yes & Yes & Yes & Yes & Yes \\
\hline Year & Yes & Yes & Yes & Yes & Yes & Yes \\
\hline Observations & 3,094 & 3,094 & 3,094 & 3,094 & 3,090 & 3,090 \\
\hline Adj-R2 & 0.0075 & 0.0074 & 0.0544 & 0.1185 & 0.0314 & 0.0002 \\
\hline $\mathrm{F}$ & $2.91 * * *$ & $3.27 * * *$ & $120.16 * * *$ & $136.55 * * *$ & $7.11 * * *$ & $7.86 * * *$ \\
\hline
\end{tabular}

Testing the relationship between board structure and firm life cycle. Table 3 presents the outcome of regressing board structure on the firm's life-cycle. To capture the relative effects of maturity and decline, we omitted the growth variable; as such, threestage variables are dummy variables. The board size in the mature stage is significantly smaller (the regression coefficient 0.094 and $\mathrm{p}<0.01$ ) compared to the growth stage. Besides, the board size in the decline stage reduces (the regression coefficient is -0.028 , and $\mathrm{p}<0.01$ ) than the growth stage. At the same time, the life-cycle effect negative to board size (regression coefficients is -0.021 and $\mathrm{p}<0.01)$ tends to decrease significantly and statistically significant, so the author accepts assuming the $\mathrm{H} 1$ hypothesis, the board size will be reduced from the growth stage to the maturity and decline stages.

The results show that board independence is decreased in the maturity stage $(\beta=-0.034, \mathrm{p}<0.1)$ compared to the growth stage. Moreover, board independence in the decline stage lower than to the growth stage $(\beta=-0.028$ and $p<0.1)$. At the same time, 
the independence board tends to reduced $(\beta=-0.013$ and $p<0.01)$ in the firm's life-cycle, so we accept the H2 hypothesis, the independence board will be decreased in the firm's life-cycle. That implies Vietnam's listed firm when IPO usually uses the board independence to attract investors but real the role of independence director not clear and not enough positive (free-rider problem) (Q. Pham et al., 2020), then this rate will decrease through stages of firm's life-cycle.

This outcome showed regressing CEO duality on the firm's life-cycle is more separated at the mature stage than at the growth stage $(\beta=-0.094, p<0.01)$. Moreover, the coefficient of decline stage is significantly negative $(\beta=-0.145, p<0.01)$, meaning that the CEO duality is also more separated at the decline stage than at the growth stage. Besides, the coefficient of the firm's life-cycle variable is negative $(\beta=-0.072, p<0.01)$, which is almost appropriate with the prediction of the separation of CEO duality in the whole firm's life-cycle (hypothesis H3).

In general, our findings showed about the board composition of Vietnam's listed firms evolving with a firm's life-cycle can be performed as follows: size and independent of board shrink during the whole firm's life-cycle, and the CEO duality will be separated. It reflects our hypothesis that the boards of Vietnam's listed firms are mostly driven by consideration of the external resources and advising function by the board's members while the monitoring function of the board's members is less paid attention. The independence of the board adjusts only to comply with Vietnamese law enforcement because the board independent does not increase with the potential severity of agency problems in the mature stage or decline stage (Li \& Zhang, 2018).

\section{Conclusion}

Given our findings, the results have shown the board of Vietnam listed firms developed according to the firm's life-cycle, specifically as follows: size and independent of board shrink during the whole firm's life-cycle, and the CEO duality will separate. This result reflects that the board composition of listed companies in Vietnam changes mainly due to the need for resources and advice brought by board members, while the supervisory function of the board members is not enough positive. This result implies support Decree 71/2017/ ND-CP on banning the chairman and CEO is one person in Vietnam listed firms. However, we propose to consider that firms need to adjust board size to a proper level promptly to improve their competitiveness because the optimal size board dynamically varies across the firm's life-cycle. Moreover, the firms should review the process of electing independent directors' members, the criteria of independent directors' members, and the performance evaluation criteria of these members because of possible members. Independent directors will not pay much attention to the performance of the task but tend to satisfy other Board members or show a free-rider role (Pham et al., 2020). Therefore, instead of force, Vietnam's listed firms to have a minimum 1/3 independent director in the board of directors, the regulator needs allow the firms to adjust their board structure independently in response to their development at different lifecycle stages.

\section{References}

Adams, R. B., \& Ferreira, D. (2007). A theory of friendly boards. The Journal of Finance, 62(1), 217-250.

Anthony, J. H., \& Ramesh, K. (1992). Association between accounting performance measures and stock prices. A test of the life cycle hypothesis. Journal of Accounting and Economics, 15(2-3), 203-227. https://doi.org/10.1016/01654101(92)90018-W

Bonn, I., \& Pettigrew, A. (2009). Towards a dynamic theory of boards: An organisational life cycle approach. Journal of Management \& Organization, 15(1), 2-16. https://doi.org/10.1017/S1833367200002844

Boone, A. L., Casares Field, L., Karpoff, J. M., \& Raheja, C. G. (2007). The determinants of corporate board size and composition: An empirical analysis. Journal of Financial Economics. https://doi.org/10.1016/j.jfineco.2006.05.004

Coles, J. L., Daniel, N. D., \& Naveen, L. (2008). Boards: Does one size fit all?. Journal of Financial Economics, 87(2), 329356.

Coles, J. L., Lemmon, M. L., \& Meschke, J. F. (2012). Structural models and endogeneity in corporate finance: The link between managerial ownership and corporate performance. Journal of Financial Economics, 103(1), 149-168.

Fama, E. F., \& Jensen, M. C. (1983). Agency problems and residual claims. The Journal of Law and Economics, 26(2), 327349.

Filatotchev, I., Toms, S., \& Wright, M. (2006). The firm's strategic dynamics and corporate governance life-cycle. International Journal of Managerial Finance, 2(4), 256-279. https://doi.org/10.1108/17439130610705481

Filatotchev, I., Yung, C. L., \& Piesse, J. (2005). Corporate Governance and performance in publicly listed , family- controlled Firms : Evidence from Taiwan. Asia Pacific Journal of Management, 22(3), 257-283. https://doi.org/10.1007/s10490-005$3569-2$

Gilson, S. C. (1990). Bankruptcy, boards, banks, and blockholders. Evidence on changes in corporate ownership and control when firms default. Journal of Financial Economics, 27(2), 355-387. https://doi.org/10.1016/0304-405X(90)90060-D

Goodstein, J., Gautam, K., \& Boeker, W. (1994). The effects of board size and diversity on strategic change. Strategic Management Journal, 15(3), 241-250. 
Hermalin, B. E., \& Weisbach, M. S. (1991). The effects of board composition and direct incentives on firm performance. Financial Management, 20(4), 101. https://doi.org/10.2307/3665716

Hillman, A. I., \& Dalziel, T. (2003). Boards of directors and firm performance: integrating agency and resource dependence perspectives. Academy Oi Management Review, 28(3), 383-396.

Jawahar, I. M., \& McLaughlin, G. L. (2001). Toward a descriptive stakeholder theory: An organizational life cycle approach. Academy of Management Review, 26(3), 397-414. https://doi.org/10.5465/AMR.2001.4845803

Jensen, M. C., \& Meckling, W. H. (1976). Theory of the firm: Managerial behavior, agency costs and ownership structure. Journal of Financial Economics. https://doi.org/10.1016/0304-405X(76)90026-X

Li, Y., \& Zhang, X. T. (2018). How does firm life cycle affect board structure? Evidence from China's listed privately owned enterprises. Management and Organization Review, 14(2), 305-341. https://doi.org/10.1017/mor.2017.55

Low, M. B., \& MacMillan, I. C. (1988). Entrepreneurship: Past Research and Future Challenges. Journal of Management, 14(2), 139-161. https://doi.org/10.1177/014920638801400202

Lynall, M. D., Golden, B. R., \& Hillman, A. J. (2003). Board composition from adolescence to maturity: A multitheoretic view. Academy of Management Review, 28(3), 416-431. https://doi.org/10.5465/amr.2003.10196743

Peng, M. W., Zhang, S., \& Li, X. (2007). CEO duality and firm performance during China's institutional transitions. Management and Organization Review, 3(2), 205-225. https://doi.org/10.1111/j.1740-8784.2007.00069.x

Pfeffer, J., \& Salancik, G. R. (1978). Social control of organizations. The External Control of Organizations: A Resource Dependence Perspective.

Pham, D., \& Pham, Q. (2020). The impact of CEO duality on firm performance: Examining the life-cycle theory in Vietnam. Accounting, 6(5), 737-747.

Pham, Q., Ho, T., Pham, D., \& Nguyen, H. (2020). Effects of corporate governance on high growth rate: evidence from Vietnamese listed companies. Management Science Letters, 10(7), 1553-1566.

Pye, A., \& Pettigrew, A. (2005). Studying board context, process and dynamics: Some challenges for the future. British Journal of Management, 16, S27-S38.

Quinn, R. E., \& Cameron, K. (1983). Organizational life cycles and shifting criteria of effectiveness: Some preliminary evidence. Management Science, 29(1), 33-51. https://doi.org/10.1287/mnsc.29.1.33

Walsh, J. P., \& Seward, J. K. (1990). On the efficiency of internal and external corporate control mechanisms. Academy of Management Review, 15(3), 421-458.

Wintoki, M. B., Linck, J. S., \& Netter, J. M. (2012). Endogeneity and the dynamics of internal corporate governance. Journal of Financial Economics, 105(3), 581-606. https://doi.org/10.1016/j.jfineco.2012.03.005

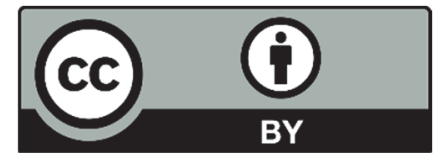

(C) 2020 by the authors; licensee Growing Science, Canada. This is an open access article distributed under the terms and conditions of the Creative Commons Attribution (CC-BY) license (http://creativecommons.org/licenses/by/4.0/). 